\title{
FROM THE DREAM TO REALITY: EXPERIENCE OF MOTHERS OF CHILDREN WITH DISABILITIES ${ }^{1}$
}

\author{
Camilla de Sena Guerra², Maria Djair Dias ${ }^{3}$, Maria de Oliveira Ferreira Filha ${ }^{4}$, Fábia Barbosa de Andrade \\ Altamira Pereira da Silva Reichert ${ }^{6}$, Verbena Santos Araújo ${ }^{7}$
}

\footnotetext{
${ }^{1}$ Paper based on the thesis - Mothers with disabled children: histories of overcoming through Integrative Community Therapy, presented (PPGEnf) to the Universidade Federal da Paraíba (UFPB) in 2014.

2 M.Sc. in Nursing. UFPB. João Pessoa, Paraíba, Brazil. E-mail: camilla_sena_@hotmail.com

${ }^{3}$ Ph.D. in Nursing. Associate Professor in PPGEnf/UFPB. João Pessoa, Paraíba, Brazil. E- mail: mariadjair@yahoo.com.br

${ }^{4}$ Ph.D. in Nursing. Faculty in PPGENF/UFPB João Pessoa, Paraíba, Brazil. E-mail: marfilha@yahoo.com.br

${ }^{5}$ Ph.D. in Health Sciences. Adjunct Professor, Universidade Federal do Rio Grande do Norte. Natal, Rio Grande do Norte, Brazil. E-mail: fabiabarbosabr@yahoo.com.br

${ }^{6}$ Ph.D. in Child and Adolescent Health. Faculty, Undergraduate Program and PPGENF/UFPB. João Pessoa, Paraíba, Brazil. E-mail: altareichert@gmail.com

${ }^{7}$ Doctoral student in PPGEnf/UFPB. João Pessoa, Paraíba, Brazil. E-mail: verbena.bio.enf@hotmail.com
}

\begin{abstract}
This study aims to show signs of emotional distress experienced by mothers of children with disabilities. Comprehensive and interpretative study, conducted in the city of Timbaúba/Pernambuco/Brazil, with six mothers of children with disabilities. The empirical material was produced by interviews, following the premises of the Oral History proposed by Bom Meihy and then interpreted in the light of the thematic analysis technique. The mothers' narratives are marked by feelings of ambiguity, neglect, sadness, denial, guilt, self-pity, self-contempt and frustrations. The stories revealed that mothers have the power to overcome and are able to adapt themselves to the experience of taking care of a disabled child. The narratives provided reflections on the complexity of being a mother, in particular, the issue of disability, suggesting the need for multidisciplinary actions aimed at personal empowerment and autonomy in caring for a child, with a view to the child's rehabilitation and inclusion in society.
\end{abstract}

DESCRIPTORS: Mother-child relationships. Psychological resilience. Nursing.

\section{DO SONHO A REALIDADE: VIVÊNCIA DE MÃES DE FILHOS COM DEFICIÊNCIA}

RESUMO: O presente estudo objetiva evidenciar sinais de sofrimento emocional vivenciados por mães de filhos com deficiência. Estudo compreensivo-interpretativo, realizado no município de Timbaúba/Pernambuco/Brasil, com seis mães de filhos com deficiência. O material empírico foi produzido através de entrevista, seguindo os pressupostos da História Oral propostos por Bom Meihy e, em seguida, interpretados à luz da técnica de análise temática. As narrativas das mães são marcadas por sentimentos de ambiguidade, abandono, tristeza, negação, culpa, autopiedade, desprezo por si mesma e frustrações. As histórias revelaram que as mães possuem poder de superação e que são capazes de se adaptarem à experiência de cuidar do filho deficiente. As narrativas proporcionaram reflexões acerca da complexidade do ser mãe, em especial, à temática da deficiência, evidenciando a necessidade de ações multidisciplinares para o fortalecimento pessoal e da autonomia no cuidar do filho, com vistas ao processo de reabilitação e inclusão deste na sociedade. DESCRITORES: Relações mãe-filho. Resiliência psicológica. Enfermagem.

\section{DEL SUEÑO A LA REALIDAD: EXPERIENCIA DE MADRES DE NIÑOS CON DISCAPACIDADES}

\begin{abstract}
RESUMEN: Este estudio tiene como objetivo mostrar signos de malestar emocional experimentado por las madres de los niños con discapacidades. Estudio comprensivo-interpretativo, realizado en la ciudad de Timbaúba/Pernambuco/Brasil, con seis madres de niños con discapacidades. El material empírico fue producido por encuestas, a partir de los pasos de la Historia Oral propuestos por Bom Meihy y, después, interpretados a la luz del análisis temático. Los relatos de las madres se caracterizan por sentimientos de ambigüedad, el abandono, tristeza, rechazo, culpa, la autocompasión, el desprecio por ella misma y frustraciones. Las historias revelaron que las madres tienen un gran poder de superación y se adaptaron a la experiencia de cuidar a los niños discapacitados. Los relatos han promovido reflexiones sobre la complejidad de ser madre, en particular, frente al tema de la discapacidad, lo que sugiere la necesidad de medidas disciplinarias para el empoderamiento personal y de autonomía en el cuidado de un niño, con objetivo hacia el proceso de rehabilitación e inclusión del mismo en la sociedad.
\end{abstract}

DESCRIPTORES: Relaciones madre-hijo. Resiliencia psicológica. Enfermería. 


\section{INTRODUCTION}

Physical and/or mental disability is a complex, dynamic and multidimensional phenomenon that influences the family, social and political context. A significant number of families exist with a disabled relative, and non-disabled people gain the responsibility to provide support and take care of disabled relatives and friends. ${ }^{1}$

The World Health Organization (WHO), based on estimates for the global population, has affirmed that, in 2010, more than a billion people around the world lived with some form of disability and that, among these, about 200 million presented significant functional difficulties, representing $15 \%$ of the global population. ${ }^{1}$

In Brazil, data from the Brazilian Institute of Geography and Statistics (IBGE), responsible for the demographic census, revealed that, in 2010, there were approximately 45.6 million people with at least some motion, sight and/or hearing difficulty, as well as people with severe limitations. In the analysis by sex, it was observed that the female population, corresponding to $26.5 \%$ (25.8 million), was more affected by at least one disability than the male population, with a percentage of $21.2 \%$ (19.8 million). ${ }^{2}$

The prevalence of at least one of the disabilities per age range was also investigated, showed a percentage of $7.5 \%$ in children between 0 and 14 years of age; $24.9 \%$ in the population between 15 and 64 years, and $67.7 \%$ in the population aged 65 years or older. The largest group, with at least one disability, was the population between 40 and 59 years, corresponding to approximately 17.4 million people, with 7.5 million men and 9.9 million women. In conclusion, based on the 2010 demographic census, the number of people who declared some kind of disability is significantly increasing. ${ }^{2}$

Studies ${ }^{3-5}$ show a considerable increase in the number of families who end up being involved in the relation with disability and its affective and emotional repercussions. The birth of a disabled child entails a series of consequences in life, behavior and the emotions of all family members and that, consequently, it can hamper the mother/ child relation, being considered one of the most significant events for a couple, with significant changes in the entire family structure. ${ }^{5}$

When the family, which up to a certain moment felt confident and knew what its role was in the birth of a child, is confronted with a diag- nosis of disability, it starts to express changes in its behavior and reveals a series of complications deriving from feelings of guilt, rejection, denial or despair, modifying the family relations and its own structure. After birth, a process similar to mourning is triggered, due to the loss of the fantasy about the perfect, healthy child. ${ }^{4-5}$

In that situation, the care delivered is solely focused on the child's disease, being considered as the only problem, so that the care is focused on the improvement of its clinical condition. Thus, the psychological aspect of the family, especially the mother, is neglected, who is left with the functions of caregiver and executor of the professionals' orders. ${ }^{6}$

The mother's role in the family context is that of holistic care provider, that is, who makes all necessary efforts to do what is best for the children, especially in case of some disability. In that context, the overriding practice of this role is socially imposed on her, often being obliged to abdicate from her personal, social and professional life to contribute as well as possible to the children's healthy development. ${ }^{7}$

In function of the love involved in this relation of dependence and the need to be potential caregivers, an attitude imposed by the marginalizing and excluding society, the mother's lack of commitment to self-care is evidenced, as they project their ways of life in function of their children's disability and, therefore, suffer and forget about themselves since the moment their children are born, extending across the lifetime. Thus, the self-forgetfulness these mothers experience demonstrates the distance they have taken from their condition of being a woman, as they simply perceive themselves as mothers of a disabled child.

The family is the base of everything, it is the eternal bond of love and compassion, of the purest friendship and of self-commitment without charges, mainly in terms of experience and the exchange of love between mothers and disabled children, which arouses characteristic feelings and reactions, such as overcoming and courage when facing the hazards of the situations experienced differently, considering that shortage produces competency, that suffering produces training. ${ }^{8}$ Thus, the author departs from the premise of psychological resilience for these mothers' psychological strengthening, which he translates as a process through which the individual can conquer the obstacles in life, thanks to his resilient effort. ${ }^{9}$ 
For many health experts, particularly in nursing, the word resilience is still new; nevertheless, professionals in the field of positive psychology and neuroscience have used it to highlight motivations that make people "overcome" traumas and adversities present in human existence. ${ }^{5}$

Encouraged by the desire to get to know the resilient and successful experiences the mothers of disabled children experience and to understand the universe of such relations, the question that permeated the research emerged: What is it like to be the mother of a disabled child? And, in the attempt to answer it, this study was intended to evidence the main signs of emotional suffering the mothers of disabled children experienced.

\section{METHOD}

To get to know the experience of mothers of disabled children, a comprehensive and interpretive study was designed, based on which the goal was to understand the aspects related to the experience and its meanings in view of the challenges in these women's daily life.

The methodological trajectory in this study was guided by the Oral History $(\mathrm{OH})$ method, more specifically the Thematic Oral History, whose objective is to clarify the narrator's opinion on some defined event, considering that the experience of being the mother of a disabled child was investigated..$^{10}$

This study was undertaken in the city of Timbaúba-PE, Brazil, between June and August 2013 in the Association of Disabled People of Timbaúba (ADAT), a philanthropic institution that is a reference for the treatment of disabilities in children between 0 and 16 years of age but which receives special cases, according to some internal criteria. In the data collection period, 80 disabled children were registered at the institution. The choice of the institution as the research scenario was due to the fact that the mothers take their children there for neuropsychomotor rehabilitation.

For the purpose of the study, the colony consisted of the mothers of disabled children with attended the ADAT, who were randomly selected when they attended the institution for meetings with a group of mothers or for care to the children. Therefore, the network consisted of six mothers who accepted and were able to participate in the study.

To execute the empirical research, the interview technique was applied, guided by cohort questions, defined as questions that cut across all interviews and should be related to the target community, constituting the identity of the group analyzed. ${ }^{11}$

The interviews were previously scheduled with the participants and recorded with their authorization. Three steps guided the entire interview process: the pre-interview, the interview itself and the post-interview, with a view to the construction of coherent discourse.

In the Oral History $(\mathrm{OH})$, due to the importance of the people's contribution, they are considered as project collaborators. This can be defined as the interviewee's name, who plays an active role and is no longer a mere research informant, actor or object, and establishes a relationship of commitment among the parties, turning into the research subject. ${ }^{12}$ The $\mathrm{OH}$ considers the testimony as a collaborator, with freedom to discuss his/her personal personal experience and participate in the entire process. ${ }^{13}$

The analysis and discussion of the documentary corpus took place after the textualization, in the post-interview phase, when the original text is reanalyzed, making it more cohesive and structured, based on exhaustive reading, in order to understand the experience, the language and the meanings expressed, identifying the vital tones of the narratives, which guide the construction of the thematic axes, based on the research objectives, among which the axis discussed here is highlighted.

To understand the empirical material, the thematic content analysis technique was applied, which "consists in discovering the cores of meanings in a communication, whose presence or frequency means something for the analytic object aimed at". 14:316 This analysis permitted the triangulation of the data, based on which the analyst interrelates his/her perceptions, the material produced (documentary corpus, vital tone and thematic axis) and the pertinent literature, with a view to deepening the perspective on the research phenomenon.

In the research process, the ethical observations addressed in the guidelines and standards of National Health Council Resolution 466/12 were adopted..$^{15}$ Approval for the research project was obtained from the Institutional Review Board of the Center for Health Sciences at Universidade Federal da Paraíba (CCBS/UFPB) on 06/18/2013, under CAEE 14725013.0.0000.5188. 


\section{RESULT AND DISCUSSION}

The experience of the mothers of disabled children is a phenomenon marked by narratives of pain, suffering and overcoming. For many mothers, it results in the strengthening of their resilience. Some of the histories pictured these women's ability to adapt to the experiences of a new course. Willing to remind society that human beings do not amount to a diagnosis, they shared common life reports, marked by unique moments with their children.

The birth of a disabled child triggers a complex and unpredictable repercussion of events in the family context. The difficulty the impact of the news entails reveals profound marks in the family members, mainly in the couple, as they feel guilty because of the loss of a dreamt, idealized and planned child. ${ }^{16}$

Being a woman contains the obligation to become the mother of a child, within the society's ideal standard. Pregnancy and successful birth can be considered a victory, as the women feel that their power/competence in the procreation task is confirmed. The birth of a disabled child, however, fragments that feeling of ability and trustworthiness, causing a slow and profound narcissistic wound that is difficult to cure, which makes the family face an extremely delicate situation, in which biased feelings towards this new being flourish. ${ }^{17}$

The mixture of feelings can be observed which reveal suffering in view of the circumstances and the pleasure of being able to help one's children, to the detriment of the unconditional love that permeates this relation, mainly when they discussed the discovery of the children's disability, in the following mothers' vital tones: it's difficult, but she made my life meaningful [...] (Isadora); [...] discovering the disability is difficult, but she's a present from God [...] (Josefa Arlúcia).

In view of the above, which affirms the potential of limitless love, despite the discovery of being the mother of a disabled child, as observed, it was permeated by fear, sadness, acceptance difficulties, as mentioned in the following testimonies: when my daughter was five months old, I gradually perceived that she had some disability, but I didn't know which [...]. When I found out, [...] I felt sad because it's very difficult to find out that your daughter will be disabled for the rest of her life [...] (Kryllane); I discovered that João Guilherme is special when he was 1 year and 4 months old, he had difficulties to talk, he didn't even say mommy and daddy. [...] it was a shock for me when I heard, great pain, it was difficult to accept, because we fantasize about a perfect child [...] (Maria de Lourdes).

These statements reveal that the discovery of the disability has the meaning of losing the perfect and expected child, with fragmented dreams, frustrated expectations and an uncertain future.

The literature highlights ${ }^{18}$ that the impact of the diagnosis, the need to adapt to the new situation, the social stigma, the dependence and the implications of the chronic nature of the clinical condition can cause a burden, conflicts, feelings of disbelief, loss of control and fear, which can compromise the ability to take care of a disabled child, as the family experiences a burnout situation.

These women's experiences are permeated by situations of intense suffering, emotional and existential conflicts, as they feel abandoned and without strength to keep on living. They want to give up the fight, finding it too painful at that time. They show their vulnerability in view of the situation experienced and are unable to apprehend the facticity of having a disabled child. ${ }^{19}$

The trajectory of difficulties emerges based on the discovery of the child's disability. Then, an experience starts that is marked by years of confusion, fear, guilt, uncertainties, self-pity, self-disdain, hours in doctor's offices, lack of clear information, increasing family problems, school battles, financial concerns, accumulated tensions, fights, normal family frustrations and the feeling of inadequacy when seeing their child, whom they love so much, increasingly take distance from the "normal" world which they would so much like to give them. ${ }^{20}$

When they are informed about the birth of a child with a syndrome or possible developmental delay, the parents face difficult times, especially concerning the interactions with their children, due to emotional factors. ${ }^{4}$ This represents a loss of the perfect child, the violation of positive expectations, causing frustrations, which some families compare with and experience as mourning. ${ }^{21}$

In the attempt to try to understand what the birth of a child represents for the parents, the author ${ }^{22}$ draws a parallel with our human concern about the impossibility to truly know the origin of life, as well as to accept its finiteness. Thus, he says that the child the parents await represents not only their immortality, but also the person who will make their unaccomplished dreams come true. 
In fact, the birth of a disabled child in the family is the birth of difference. A true problem the family is confronted with, with countless attempts to deny it, although that is not possible. The family will have to elaborate the death of the idealized child. It is the shock between the ideal and the reality that is distant from the dream. ${ }^{23}$

The suffering deriving from a loss is one of the most difficult and challenging processes of human existence. Dealing with the death of the idealized child implies dealing with a subject who does not fit into the pre-established parameters of normality. The birth of the different leads to stigmatization. The disabled child's family sometimes denies or rejects him/her. ${ }^{23}$

The statements below evidence the suffering and repercussion this feeling of loss caused in the collaborators' life: I have already thought of various silly things, sometimes I yell, I talk aloud, once I got desperate and said: God! Take away mine and my daughter's life, because it's better to die, because I can't stand this life I am leading, I can't take it anymore! I can't get by it [...]. Why did you give me a special child? [...] I am unable to be the mother of a special child, I am too weak for that (Krysllane); [...] I used to complain so much of God, when I was crying, I though: God doesn't look out for me! And I said: what did I do to you, God, to make me suffer that much? (Rejane); I didn't accept it, being my first child, and I kept on asking myself why God had given me a special child, instead of a child who to our eyes is perfect. It was very difficult for me to go out with him, to deal with other people, like, great prejudice departing from myself. It was very difficult for me to accept that my child is special, I imagined that he would be perfect, but I could perceive that nothing in this world is perfect. I had to have a special child, with his difficulties and limitations, to perceive that what I had dreamt did not become true (Maria de Lourdes); I had a healthy pregnancy and took care of myself so well, and why? Why me? (Isadora).

The feelings of sadness, disappointment and frustration are part of the mourning that these mothers experience, which is linked to the loss of the perfect and idealized child and to the feeling of maternal impotence for having generated an imperfect child. All mothers experience this feeling in view of the news that their child will have a developmental delay, that is, be disabled. ${ }^{24}$

The psychological trauma results from a situation the individual experiences, witnesses or is confronted with, which represented a threat to one's own or related people's physical and/or psychological integrity. ${ }^{25}$
Denial is a mental mechanism that is operated unconsciously to solve an emotional conflict and relieve the subsequent anxiety, denying some important elements; the feelings denied can be thoughts, desires, needs and even realities. ${ }^{26}$

The statements revealed this situation: [...] I decided to raise him as if he were a normal child. That was real to me, my child was not special! (Marilene); [...] the doctor said she doesn't even have a delay anymore [...] (Isadora).

Some of the histories narrated here are intertwined with situations that caused suffering and that, despite being inherent to the human being's existence, this network contains common traits that compose similar trajectories. But, amidst that much pain, denial and suffering, the phenomenon of strengthening resilience happens, through which the collaborators regain their selfawareness, strengthen their self-esteem, recover the autonomy they had lost, whether with support from spirituality, from the family, from empowerment or participation in groups at ADAT.

Resilience is the human being's ability to come out of the adversity stronger, with more resources, and to transform situations of risk and vulnerability into potentials. It is an active process of resistance to restructuring and growth in response to the crisis and challenge, allowing the individuals to be transformed by these potentially stressing factors, adapting to or overcoming these traumatic and/or stressful experiences. ${ }^{27}$

Resilience is a tool of fundamental human transformation, as it enables the individuals to transform themselves and the reality they live in, besides offering the condition to fin, in and around themselves, all elements that allow them to create this ability to overcome. ${ }^{5}$

Therefore, it is when coping with the difficulties that people produce constructive knowledge, formulating mechanisms of overcoming. Resilience is imbued in the entire lifecycle, as it is active, dynamic and permits reconstruction based on the ability to resist and grow in adversity, to the extent that it stimulates the autonomy and strengthens the interpersonal bonds. ${ }^{28}$

The narratives reveal phrases that express the collaborators' feelings towards the strengthening of resilience: it was the best thing God gave me (Krysllane); she made my life meaningful (Isadora); it's a gift God gave me (Josefa); being the mother of a special child is overcoming (Maria de Lourdes). 
The statements observed revealed important aspects to develop resilience, as they reveal each collaborator's power to overcome, in view of her life stories. The resilient, which produces the overcoming, derives from the suffering and the desire to change the reality, such a peculiar characteristic of the human species, considering that "an oyster that was not wounded does not produce a pearl. The pearls are responses to the aggressions. Therefore, we need to be cautious to react and leave, not from an unpleasant moment for the other, but in search of overcoming and growth" 8:3467

To reach the stage of overcoming, that is, to awaken the resilient power, these mothers went through a process of acceptance though, which is the mechanism in which the individuals have already elaborated the behaviors associated with the other stages, such as denial, sadness, annulment and acceptance of or resignation to the loss. ${ }^{26}$

The statements below reveal how the collaborators' reactions of acceptance were manifested, in view of the discovery of their children's disability: it is only after I started taking the graduate program that I got interested, I started researching more about his disease, so today I see that my son is truly a special child... (Marilene); I am able to live with that now, I was unable to live before [...] (Krysllane); but I don't cry anymore today, God know it was because I didn't have the understanding I have today [...] (Rejane); over time, I have been able to accept the way he is better [...] Today, I have a different way of thinking about it for some time [...] (Maria de Lourdes).

The acceptance these mothers express is the way to construct a bond, constituted between mother and child, which was weakened until then due to the mourning process they and their relatives were experiencing. Based on the acceptance, mother and family start to include this child in society, breaking paradigms and prejudices imposed on such defenseless beings who, since early, gain strength and vigor to fight and win, in view of the obstacles the capitalist society imposes. This society is rooted in mercantilist premises and only takes interest in what the individual can do and produce and, when they do not fit into this pattern, they are excluded, segregated and live adrift.

As soon as the parents take the first step and accept their children, they start to love them and include them in society. They are seen with other eyes. New forms of overcoming the prejudices are built, based on confidence and self-esteem, resulting in empowerment.
Empowerment emerges as we gain awareness of our strength to surpass ourselves, which is resilience. It emerges when we understand and accept to be active subjects in society, learning from our history without being ashamed of our origins, cultural values, constituted by our ancestors. ${ }^{8}$

In view of this notion of empowerment, it was perceive how much these mothers were psychologically strengthened, facing the moments of pain and difficulties experienced with the child, surpassing barriers and including their children in society.

Individuals are inserted in society as soon as they actively participate in the construction of the community's daily life. Each person's daily activities are related to the activities of his/her family, friends, colleagues from work, constituting a network of social relation linked to these different activities. Being included in this social midst demands the organization of a daily life that can lead to a continuous interaction with the other people around him/her and with the society's production mode. ${ }^{29}$

In view of the above, the mothers experience moments of sharing with the disabled child, when they become eternal learners and reduce the distance that separates them and the negative conditions of life, that is, when they learn to seek the route to happiness together, encouraged by the desire to enrich themselves, overcoming the barriers the post-modern, fluid and weakened society imposes.

It is important for the health professionals to enter this universe of exclusion and prejudices, working in favor of these individuals' inclusion in the society, through care that is specifically focused on their needs and anxieties and, above all, helping the mothers to accept their children with their disabilities but, mainly, with their possibilities.

A study developed in Italy supports this assertion, assessing the relation between 581 premature infants with severe neuromotor and/ or sensory disability and the mothers' mental healthy, revealing high levels of mental suffering in $31 \%$ of the mothers due to the child's condition, appointing the importance of health professionals' support. ${ }^{30}$

\section{FINAL CONSIDERATIONS}

The birth of a disabled child represents a universe of challenges for the parents. There are countless situations that contribute positive or 
negatively to family life. Many difficulties are experiences, including tiresome care when dealing with the child, facing the prejudice of society, and so many other challenges these families are confronted with.

In the study, unusual and often conflicting revelations were made regarding the feelings that emerged in the relations between the mothers and disabled children and the difficult and harsh task of taking care and fully dedicating themselves to them. Many mothers revealed feelings of ambiguity, abandonment, sadness, denial, guilt, self-pity, self-neglect and frustrations, but they revealed that the moments of pain and the difficulties they faced with their children made them learn to surpass the barriers and prejudice, maturing and learning to turn into strong people who believe in a better world, as well as more inclusive and less prejudiced society.

The construction of this study gave rise to reflections that characterize the complexity of being a mother, especially regarding disability. Throughout the construction process, relevant determinations appeared that should be rescued and reaffirmed.

The mothers' discourse represented lessons of life and overcoming, being women marked by a life of exclusive and comprehensive dedication to their children, discovering each day how to cope with the suffering and exclusion, building unbreakable bonds that are permeated by the true love that only exists between mothers and children, even in a society loaded with superficial and fluid relationship, far from what is desired and expected for eternal affective bonds.

This study came with some limitations, mainly related to the number of mothers interviewed, as well as the fact that the study was local. It should also be highlighted that, although the study addresses the emotional suffering the mothers of disabled children experience, this is not an absolute reality for all mothers who experience this condition. Nevertheless, it allowed us to reflect on the complexity of the disability theme, involving the mother-and-child relationship.

In that context, the research significantly contributed to allow nursing to direct its clinical and mainly humanized look towards distinguished care for these mothers, based on a holistic approach, from the perspective of social inclusion, which permits knowing a bit of these women's universe, which shows the suffering they experience. As these mothers simply perceive themselves as mothers of a disabled child, they take distance from their condition of being women, forgetting about themselves and self-care.

Therefore, nursing should further engage in this kind of issues, entering the world of inclusion to plant new seeds of a particular, distinguished care that is mainly permeated by a lot of love, without fear of coping with the adversities and facing new challenges, such as working with binomials like mothers and children in situations of exclusion, as well as other potentially vulnerable and/ or weakened and marginalized binomials.

Based on the study results, the researchers expect to contribute to further research focused on the histories of mothers with disabled children, since the discovery until the process of accepting and overcoming, thus leading to the consolidation of a care practice focused on the mother, with multidisciplinary actions for personal strengthening and greater autonomy in care for the children, with a view to the rehabilitation process and inclusion in society.

\section{REFERENCES}

1. Organização Mundial da Saúde. Relatório mundial sobre a deficiência. Tradução Lexicus Serviços Lingüísticos. São Paulo (SP): SEDPcD; 2011.

2. Instituto Brasileiro de Geografia e Estatística (IBGE). Censo demográfico: Contagem Populacional 2010. Brasília (DF): IBGE; 2011.

3. Falkenbach AP, Rosa L. A formação de vínculos afetivos na relação primaria mãe/criança com deficiência. Rev Digital [online]. 2009 Jun [acesso 2014 Fev 09]; 14(133). Disponível em: http:/ / www. efdeportes.com/efd133/relacao-primaria-maecrianca-com-deficiencia.htm

4. Milbrath VM, Soares DC, Amestoy SC, Cecagno D, Siqueira HCH. Mães vivenciando o diagnóstico da paralisia cerebral em seus filhos. Rev Gaúcha Enferm. 2009 Set; 30(3):437-44.

5. Thuy NTM, Berry HL. Social capital and mental health among mothers in Vietnam who have children with disabilities. Glob Health Action. 2013 Feb; 6: 1-12.

6. Gondim KM, Pinheiro PNC, Carvalho ZMF. Participação das mães no tratamento dos filhos com paralisia cerebral. Rev Rene. 2009 Out-Dez; 10(4):136-44.

7. Bastos OM, Deslandes SF. A experiência de ter um filho com deficiência mental: narrativas de mães. Cad Saúde Pública [online]. 2008 Set [acesso 2014 Fev 09]; 24(9):2141-50. Disponível em: http:/ / www.scielo.br/scielo.php?script=sci_ arttext\&pid=S010211X2008000900020\&lang=pt 
8. Braga LAV, Dias MD, Ferreira Filha MO, Moraes MN, Araruna MHM, Rocha IA. Terapia comunitária e resiliência: história de mulheres. Rev Pesqui Cuid Fundam. [online]. 2011 Dez [acesso 2014 Fev 09]; (supl):251-68. Disponível em: http://www.seer. unirio.br/index.php/cuidadofundamental/issue/ view/79

9. Barreto AP. Terapia comunitária passo a passo. Fortaleza (CE): Gráfica LCR; 2008.

10. Bom Meihy JCS, Holanda F. História oral: como fazer, como pensar. São Paulo (SP): Contexto; 2011.

11. Bom Meihy JCS. Guia prático de história oral. São Paulo (SP): Contexto; 2011.

12. Dias MD. Mãos que acolhem vidas: as parteiras tradicionais no cuidado durante o nascimento em uma comunidade nordestina [tese]. São Paulo (SP): Universidade de São Paulo, Programa de PósGraduação em Enfermagem; 2002.

13. Souza KRF, Dias MD. História oral: a experiência das Doulas no cuidado à mulher. Rev Acta Paul Enferm. 2010; 23(4):493-9.

14. Minayo MCS. O desafio do conhecimento: pesquisa qualitativa em saúde. $11^{\mathrm{a}}$ ed. São Paulo (SP): Hucitec; 2008.

15. Ministério da Saúde (BR). Conselho Nacional de Saúde, Comissão Nacional de Ética em Pesquisa. Resolução n 466 de 12 de dezembro de 2012: diretrizes e normas regulamentadoras de pesquisa envolvendo seres humanos. Brasília (DF): MS; 2012.

16. Falkenbach AP, Drexsler G, Werler V. A relação mãe/criança com deficiência: sentimentos e experiências. Cien Saude Colet. 2008; 13(2):2065-73.

17. Milbrath VM, Cecagno D, Soares DC, Amestoy SC, Siqueira HCH. Ser mulher mãe de uma criança portadora de paralisia cerebral. Acta Paul Enfermagem. 2008; 21(3):427-31.

18. Barbosa MAM, Balieiro MMFG, Pettengil MAM. Cuidado centrado na família no contexto da criança com deficiência e sua família: uma análise reflexiva. Texto Contexto Enferm. 2012; 21(1):194-9.

19. Barbosa MAM, Chaud MN, Gomes MMF. Vivências de mães com um filho deficiente: um estudo fenomenológico. Acta Paul Enferm. 2008; 21(1):4652.
20. Buscaglia L. Os deficientes e seus pais. Rio de Janeiro (RJ): Record; 2006.

21. Vieira SS, Dupas G, Bevilacqua MC, Ferreira NMLA. Descoberta da deficiência auditiva pela família: vendo o futuro idealizado desmoronar. Acta Paul Enferm. 2012; 25(2):82-8.

22. Góes FAB. Um encontro inesperado: os pais e seus filhos com deficiência mental. Psicol Ciênc Prof. 2006; 26(3):450-461.

23. Silva KGP, Duarte LC. O excepcional na família e na instituição: deficiente ou sujeito? Relatório de estágio da disciplina Psicologia do Excepcional II, FCHFUMEC. Belo Horizonte (MG): Ibirité-BH; 1998.

24. Luza AR, Ceccheto FH, Silva EF. Sentimentos e dificuldades enfrentadas por mães de crianças com necessidades especiais. Rev enferm UFPE online [online]. 2011 Ago [acesso $2014 \mathrm{Fev}$ 09]; 5(6):1397402. Disponível em: http://www.revista.ufpe.br/ revistaenfermagem/index.php/revista/article/ viewArticle/1636

25. Peres J. Trauma e superação: o que a psicologia e a neurociência e a ensinam. São Paulo (SP): Roca; 2009.

26. Towsend MC. Enfermagem psiquiátrica: conceitos de cuidados. $3^{\mathrm{a}}$ ed. Rio de Janeiro (RJ): Guanabara Koogan; 2002.

27. Ferreira CL, Santos LMO, Maia EMC. Resiliência em idosos atendidos na Rede de Atenção Básica de Saúde em município do nordeste brasileiro. Rev Esc Enferm USP. 2012; 46(2):328-34.

28. Morais FLSL. Rodas de Terapia Comunitária: espaços de mudanças para profissionais da estratégia saúde da família [dissertação]. João Pessoa (PB): Universidade Federal da Paraíba. Programa de Pós-Graduação em Enfermagem; 2010.

29. Salles MM, BarrosS. Vida cotidiana após adoecimento mental: desafio para atenção em saúde mental. Acta Paul Enferm [online]. 2009 [acesso 2014 Fev 09]; 22(1):11-6. Disponível em: http://www.scielo.br/ pdf/ape/v22n1/a02v22n1.pdf

30. Cacciani L, Di Lallo D, Piga S, Corchia C, Carnielli $\mathrm{V}$, Chiandotto $\mathrm{V}$, et al. Interaction of child disability and stressful life events in predicting maternal psychological health. Results of an area-based study of very preterm infants at two years corrected age. Res Dev Disabil. 2013; 34(10):3433-41. 